\title{
Neutrality and Nonalignment in World Politics during the Cold War
}

\section{Fischer, Thomas}

2016-12-01

Fischer , T , Aunesluoma , J \& Makko , A 2016 , ' Neutrality and Nonalignment in World

Politics during the Cold War' , Journal of Cold War Studies, vol. 18 , no. 4 , pp. 4-11 . https://doi.org/10.1162/JCWS

http://hdl.handle.net/10138/232330

https://doi.org/10.1162/JCWS_a_00677

publishedVersion

Downloaded from Helda, University of Helsinki institutional repository.

This is an electronic reprint of the original article.

This reprint may differ from the original in pagination and typographic detail.

Please cite the original version. 


\title{
Introduction
}

\section{Neutrality and Nonalignment in World Politics during the Cold War}

\author{
$\because$ Thomas Fischer, Juhana Aunesluoma, \\ and Aryo Makko
}

"In the past, neutrality was normal. Today, it is exceptional." Thus wrote Philip Windsor, a noted teacher and scholar of international relations at the London School of Economics and Political Science, in a book published in 1989 on European neutrality and non-alignment. ${ }^{1}$ If Windsor's assessment was correct in the late 1980s, the end of the Cold War soon thereafter seemingly made neutrality not only exceptional but nearly extinct. Not so for Cold War historians, however.

In the early 1990s, historical research on Cold War neutrality entered a new phase. With access to declassified archival sources, historians were able for the first time to reconstruct in detail and analyze how Cold War neutrality had evolved as a policy and practice. In some cases research was conducted through government-sponsored programs or appointed commissions that looked at contentious or politically sensitive issues, such as the neutral states' position in the strategic and operational military planning of the North Atlantic Treaty Organization (NATO) and the Warsaw Pact, in the intelligence activities conducted by NATO and Warsaw Pact member-states, and in the comparisons between declaratory foreign policy and its actual execution.

As a result of more than two decades of scholarship, research on Cold War neutrality has taken a significant leap forward. Based on a continual flow of new archival findings, the image of the four European "classic" neutrals-Austria, Finland, Sweden, and Switzerland-has changed considerably. Scholars have shed light on how neutrality functioned as a part of the Cold War international system. In particular, recent analyses of Cold War neutrality have stressed

1. Philip Windsor, "Neutral States in Historical Perspective," in Joseph Kruzel and Michael H. Haltzel, eds., Between the Blocs: Problems and Prospects for Europe's Neutral and Nonaligned States (Washington, DC: Woodrow Wilson Center Press, 1989), pp. 3-9.

Journal of Cold War Studies

Vol. 18, No. 4, Fall 2016, pp. 4-11, doi:10.1162/JCWS_a_00677

(C) 2017 by the President and Fellows of Harvard College and the Massachusetts Institute of Technology 
the importance of neutrality's domestic political and ideational dimensions (neutrality as domestic politics) and its connections to foreign policymaking (neutrality as foreign policy).

Research linking the domestic sphere with neutrality policy has been one of the most important contributions to the new Cold War neutrality scholarship. However, and similar to the research on neutrality as foreign policy and in strategic studies, these efforts have often continued to follow a strictly national approach. ${ }^{2}$ Up to now, no attempt has been made to compare the results of these studies. ${ }^{3}$ Hence, in late 2010 we organized a workshop at the Graduate Institute of International and Development Studies in Geneva to take stock of the new findings and allow the research on European neutral states to be put in the broader analytical framework today known as the "new" Cold War history. ${ }^{4}$ In putting together this themed issue, we hope to assist scholars of the Cold War and the history of neutrality in identifying missing and/or underrated aspects in the debate and in defining fresh and stimulating research perspectives.

Neutrality has been repeatedly declared extinct in light of the advancing European integration process and global changes since the end of the Cold War. Nevertheless, it has remained an issue of interest and a matter of political debate in the countries under scrutiny here. This is mostly because of domestic political and ideational considerations, but the outbreak of a crisis over Crimea in 2014 led to new calls for neutrality being voiced internationally, for example by Henry Kissinger, one of the most prominent foreign policymakers of the past century. ${ }^{5}$ Although it is unclear whether the concept of neutrality will

2. The notable exception is Johanna Rainio-Niemi, The Ideological Cold War: The Politics of Neutrality in Austria and Finland (New York: Routledge, 2014).

3. Three publications of more recent date, however, deserve to be mentioned, insofar as they provide important English-language surveys of a select number of neutral states or of a topic also presented in this issue: Thorsten B. Olesen, ed., The Cold War-and the Nordic Countries: Historiography at a Crossroads (Odense: University Press of Southern Denmark, 2004), including contributions on Sweden and Finland; special issue, Cold War History, Vol. 8, No. 2 (2008), dealing with national and international approaches to teaching and research in Cold War history, including contributions on neutral Switzerland and the Scandinavian countries; and Michael Gehler and Rolf Steininger, eds., The European Neutrals and European Integration 1945-1995 (Vienna: Böhlau, 2000), giving a complete overview of the European neutrals and the history of the European integration process during the Cold War.

4. Odd Arne Westad, "Review Essay: A 'New' International' History of the Cold War?” Journal of Peace Research, Vol. 32, No. 4 (1995), pp. 483-487.

5. On the domestic dimensions and ideational character of neutrality, see the contributions collected in Christine Agius and Karen Devine, eds., "Neutrality and 'Military Non-alignment': Exploring Norms, Discourses and Practices," special issue, Cooperation \& Conflict, Vol. 46, No. 3 (2011). For Kissinger on Crimea, see Henry Kissinger, "How the Ukraine Crisis Ends," The Washington Post, 5 March 2014, p. A17. Kissinger avoids the term "neutrality," recommending Finland's "fierce independence" as a 
take full root in the Euro-Atlantic strategic context, the past two decades of domestic consensus- and post-Cold War identity-building have become a key element in our understanding of European Cold War neutrality. The main argument in each of the country studies included in this issue is that neutrality has remained a potent issue for domestic reasons that emerged or continued long after neutrality had outlived its original functions of providing security and stability in Europe. At the same time it has become evident that the conceptualization of neutrality and the policies associated with it during the Cold War varied in each neutral state-depending on that state's individual historical, geostrategic, political, economic, and cultural situation-and in reality remained narrowly defined by the maneuvering room within which the superpower-led blocs allowed the neutral states to negotiate. To this end, two contributions on the superpowers' perspectives on neutrality complement the individual country studies in this special issue.

Because the subject of international neutrality is rather remote for most scholars of Cold War history, an introductory clarification of basic terms will allow a proper assessment of how the different neutral states understood neutrality. ${ }^{6}$ The concept of neutrality was developed in Europe mainly during the eighteenth and nineteenth centuries. The term stems from the Latin ne uter, meaning "neither of two," and basically meant non-participation in a war between other states. Neutrality has both a legal and a political dimension. The legal basis of neutrality was drawn up at the beginning of the twentieth century in a code of regulations enshrined in the Hague Conventions of 1907, which outlined the conduct of neutral states in time of war. Although this set of rules may seem outdated at the beginning of the 21 st century, it still represents neutrality's legal core.

The most important aspect of the Hague rules is a neutral state's right to the inviolability of its territory and a respect for the integrity of its neutral status by warring parties. However, in accordance with the principle of abstention, the neutral state must not itself provide any military assistance to belligerents. A neutral state must also impede or repulse any military activities by the belligerents on its territory, in its airspace, and in its territorial waters. By virtue of the obligations of equal treatment, neutral states must apply

posture. In response, however, Finland's Prime Minister Jyrki Katainen declared that Finland "was not neutral." See "Katainen: Finland Is Not Neutral, NATO Is an Option," Yle Uutiset, 16 March 2014, p. 8. http://yle.fi/uutiset/katainen_finland_is_not_neutral_nato_is_an_option/7139523.

6. Definitions are taken from Thomas Fischer, Neutral Power in the CSCE: The N+N States and the Making of the Helsinki Accords 1975 (Baden-Baden: Nomos, 2009), pp. 29-32. See also Jürg Martin Gabriel, The American Conception of Neutrality after 1941, rev. ed. (New York: Palgrave Macmillan, 2002), pp. 9-16. 
whatever non-military measures they decide to take, such as export restrictions and embargoes, to all belligerents equally. Finally, the neutral states are to abide by certain restrictions imposed by the belligerents, including limits on international transports and trade.

In international law, distinctions are further drawn between occasional (ad hoc, temporary) and permanent (perpetual, everlasting) neutrality. A country is occasionally neutral when it declares neutrality in a particular war and only for the duration of that war. A country is permanently neutral when it commits itself to remain neutral in all future wars, as Switzerland did upon signing a multilateral agreement with the great powers at the Congress of Vienna in 1815, or as Austria did in a unilateral declaration in 1955 that was followed by international recognition. By contrast, Sweden's and Finland's neutral status has no domestic or international legal foundation. Instead, it is based on their foreign policy traditions and unilateral commitment to uphold a policy of neutrality. The Swedish and Finnish status is therefore termed "de facto permanent neutrality." This sort of permanent neutrality can, in principle, be abandoned at any time. However, because the two states' international credibility relies heavily on the predictability of their neutrality, both states during the Cold War tended to follow the same patterns as the permanently neutral Switzerland and Austria under international law. Within the context of the East-West conflict, each of the neutral states had to make absolutely clear that it would never start a war or enter into one unless the state itself was attacked.

During times of war, no distinction is made between the rights and obligations of an occasionally neutral state and those of a permanently neutral state. In peacetime, however, permanent neutrality extends the strict legal terms of the Hague Conventions, and restrictions on the countries' foreign policy are adopted regarding the political dimensions of neutrality. Neutrality policy, or a policy of neutrality, comprises all measures intended to strengthen and protect the law of neutrality. Such a policy has no foundation in law but is mainly defined through customs and practice. As Jürg Martin Gabriel writes,

For an occasional neutral country, this embraces actions to prevent being drawn into a particular ongoing conflict. For a permanent neutral power, the implications are broader: it should do nothing to undermine the practicability and, equally important, the credibility of its neutrality in a future war. A permanent

7. The qualification of Liechtenstein as another de facto permanently neutral state in the Cold War is contested because the principality never explicitly stated its ambitions for perpetual neutrality and because its foreign affairs were for so long closely linked to those of Switzerland. 
neutral, therefore, should not enter into peacetime alliances or permit the estab-

lishment of foreign military bases on its soil. ${ }^{8}$

Each of the neutrals discussed in this special issue clearly falls into the latter category: each has abstained from joining military alliances, and each has prevented foreign troops from being stationed on its territory. As a result, the four European neutrals have prepared to defend themselves against aggression by relying on their armed forces, leading to the emergence of the concept of armed neutrality as a national security strategy. Most of the neutral states went even further during the Cold War. They ensured that their foreign trade policies would uphold the credibility of neutrality policy and avoid economic dependencies that would prevent them from maintaining neutrality in time of war. ${ }^{9}$

The legal and political definitions of neutrality did not require the citizens of a neutral country to follow any kind of ideological or "moral neutrality." Indeed, none of the four European neutrals was considered ideologically neutral in the battle of ideas of the Cold War. All four had societies culturally oriented to the West, with states deeply rooted in liberal traditions, democratic systems of government, and the principles of private property and a market economy.

The inclusion of Lorenz Lüthi's article on the Non-Aligned Movement and the Cold War, in this special issue necessitates a further distinction between the terms "neutrality" and "non-alignment" (or "neutralism"; in German, Blockfreiheit). ${ }^{10}$ The term "non-alignment" is of more recent origin than "neutrality," having emerged from within the context of decolonization and the Cold War during the 1950s. Many newly independent states refused to align themselves with either of the two contending superpowers or to take a stand in their conflict. The nonaligned states shared an obligation with the neutral countries to remain outside the bloc structures. Non-alignment, however, is neither legal in nature nor based on any neutral rights and duties. Nor is it related to permanent neutrality. Nonaligned states have gone to war when

8. Gabriel, The American Conception of Neutrality, p. 12.

9. This is also the main criterion separating the "classic" neutrals Austria, Finland, Sweden, and Switzerland from the case of Ireland, which joined the European Community as a neutral state as early as 1973. Ireland's neutrality was never seen as equivalent to the neutrality of the other European neutrals at the time and was mainly understood as a historical function of its national independence policy vis-à-vis Great Britain. Telling in this regard is the omission of Ireland from the high-level four-party talks held during the later Cold War years among the neutral foreign ministries.

10. Definitions are taken from Fischer, Neutral Power in the CSCE, pp. 31-32. See also Hanspeter Neuhold, "Permanent Neutrality and Non-alignment: Similarities and Differences," Österreichische Zeitschrift für Aussenpolitik, Vol. 19, No. 1 (1979), 79-100; Vladimir Bilandžić and Stanko Nick, "The Policy of Non-Alignment of Yugoslavia," in Karl E. Birnbaum and Hanspeter Neuhold, eds., Neutrality and Non-Alignment in Europe (Vienna: Wilhelm Braumüller, 1982), pp. 168-195. 
doing so has served their national interest. The criteria for a nonaligned country were summed up at the preparatory meeting of the nonaligned movement's first conference in 1961:

A nonaligned country should adopt an independent foreign policy based on co-existence of States with different political and social systems and on nonalignment, or should be showing a trend in favour of such a policy, and consistently support movements of national independence. Such a State must not be a member of a multilateral military alliance concluded in the context of the Great Power conflict; if it has a bilateral military agreement with a Great Power or if it is a member of a regional defense pact, such an agreement or pact should not be deliberately concluded in the context of the Great Power conflicts.

Non-alignment is a political concept based on morality, with a clear intention to promote efforts toward peace, security, and stability in international relations. Non-alignment originated in India and reached its international heyday in September 1961 with the Declaration of the Heads of State or Government of the 25 nonaligned countries in Belgrade. Collectivism was another essential characteristic of the nonaligned movement in the Cold War. Whereas neutrality is an institution of specifically European origin, non-alignment sprang up among African, Asian, and Latin American countries. In Europe the movement was originally represented by Yugoslavia and Cyprus, followed later by Malta. ${ }^{11}$

In the European Cold War context, non-aligned and permanently neutral states conformed in their characteristics insofar as both opted for a non-bloc policy with regard to NATO and the European Community and the Warsaw Pact and the Council for Mutual Economic Assistance. In contrast, the nonaligned and permanently neutral states differed most obviously in the legal status of their non-alignment/neutrality. Whereas permanent neutrality was defined by a code of international law regulating relations between belligerent and non-belligerent states, non-alignment was based on no such legal criteria. Non-alignment comprised more than just the ambition to stay out of armed conflicts; it included such goals as democratization of the international system, the reform of the world economic order, and the safeguarding of national sovereignty, as well as — in the case of Yugoslavia — certain objectives of socialist internationalism.

The four European neutrals can be grouped into various constellations, depending on the criteria one chooses to examine. In addition to differing

11. Malta in 1982 even formally proclaimed itself a neutral state, but this status was recognized only by Italy. 
legal bases, the historical roots, domestic context, and geostrategic position of each country are also important in their definitions of neutrality, with consequences for the four neutrality concepts that emerged within the European Cold War. That is, Switzerland pursued a universal outlook for its neutrality policy, whereas Austria's neutrality, a direct offspring of the superpower conflict in Europe, was oriented more toward accentuating Austria's profile between East and West. In Sweden and Finland, neutrality was developed within a subregional Nordic context. Given Sweden's active engagement in the United Nations (UN), the country's neutrality also offered an idealistic and activist global dimension that the Swiss, despite their universal outlook as a non-member of the UN, could not follow. Sweden and Switzerland, however, were notably less exposed to Soviet pressure than were Finland and Austria, geostrategically positioned at the outskirts of Western Europe. Given these circumstances, Finnish neutrality focused on national sovereignty and independence, whereas in neighboring Sweden the main function of neutrality was to secure national interests by ensuring the maintenance of a strategic balance in Northern Europe.

A common link between Swedish, Finnish, and Austrian neutrality during the Cold War was these countries' outward-looking approach, whereas Switzerland was slow in departing from its historically isolationist concept of neutrality. As the articles in this special issue illustrate, this legacy is-to some degree-still reflected today. Of the four neutral countries, Switzerland is the only one that has remained outside the EU. Sweden, Finland, and Austria joined it after the end of the Cold War, in 1995. Only Austria and Switzerland still hold to the concept of neutrality in their foreign and security policies. Sweden and Finland no longer use the term in their official doctrines, and both have openly contemplated the prospect of joining NATO.

\section{Acknowledgments}

The articles dealing with European Cold War neutrality presented in this special issue are the result of the "European Cold War Neutrality: A Historical Reappraisal" workshop held at the Graduate Institute of International and Development Studies in Geneva in October 2010. The editors thank the Swiss National Science Foundation, the Network for European Studies at the University of Helsinki, the History Department at Stockholm University, and the International History Department of the Graduate Institute of International and Development Studies in Geneva for their financial contributions to the 
workshop. Jürg Martin Gabriel, Jussi Hanhimäki, Magnus Petersson, Helge Pharo, Neville Wylie, and Sacha Zala contributed to the individual articles with useful comments during the workshop. We also thank the editor of the journal, Mark Kramer, as well as the anonymous reviewers for their help and advice in realizing the special issue. 
Copyright of Journal of Cold War Studies is the property of MIT Press and its content may not be copied or emailed to multiple sites or posted to a listserv without the copyright holder's express written permission. However, users may print, download, or email articles for individual use. 